\title{
The post-secular in post-war American religious history
}

\author{
K. Healan Gaston
}

\begin{abstract}
Introduction
Anyone who has paid attention to post-secular discourse knows that the 1990s and early 2000s brought a veritable explosion of self-consciously 'post-secular' theorizing across a wide range of disciplines and moral communities. Religious thinkers increasingly latched on to poststructuralist critiques of scientific rationality and adapted them to their own purposes, while interest in religion also spread rapidly among secular philosophers and political theorists. Jürgen Habermas's post-secular turn and the debates around Charles Taylor's A Secular Age (2007) built on the developments of the 1990s and gave the burgeoning post-secular discourse additional momentum.

However, the 'post-secular' category itself has much deeper roots in American intellectual life. Like many early expressions of the postmodern, the post-secular can be traced back to an earlier generation of religious critics whose sensibilities were decisively shaped by American developments in the decades after World War II. In particular, the term emerged in the 1950s and early 1960s as interpreters of American religion clashed over the authenticity of the so-called 'post-war religious revival' and the shape of the religio-political future. Although many of these commentators argued that the moral shallowness and consumerism of much post-war religiosity reflected a secularizing impulse within the faith traditions themselves, other observers contended that what looked like secularization actually signalled the emergence of a new phenomenon, 'civil religion'. Still others viewed secularization itself positively, contending that religious groups could create more robust and fulfilling forms of faith by engaging this fruitful new social condition. As these divergent interpretations of the twentieth-century religious scene carried forward through the 1980s and 1990s, they continued to create discursive spaces wherein post-secular constructions flourished.

Like many of the other terms discussed in this book, the 'post-secular' construct often announced the impending arrival of a new age, even as
\end{abstract}


it portrayed the era just ending in specific, controversial ways. Few of its users, moreover, were shy about their normative ambition to bring a postsecular world into being. This chapter illustrates those dynamics by examining a number of key moments in the early development of post-secular discourse, while keeping an eye on what they tell us about contemporary preoccupations with the category. The earliest post-secular constructions, like the broader discourse of 'secularism' itself, tended to identify both unbelief and theological liberalism as threats to genuine religion - and, in many cases, to challenge strict readings of the First Amendment's call for separation of church and state.

\section{Early experiments: Martin Marty, Andrew Greeley and Will Herberg}

The earliest scholarly invocations of the term 'post-secular' came from the Lutheran pastor and historian Martin E. Marty and the Catholic priest, sociologist, and novelist Andrew M. Greeley. Born on the same day in 1928, Marty and Greeley shared a generational consciousness shaped by the crisis of World War II during their adolescent years. ${ }^{1}$ Each made his career at the University of Chicago and in Chicago-area churches. Marty received his $\mathrm{PhD}$ from the University of Chicago in 1956 and then taught there from 1963 to 1998, while also leading a suburban church nearby from 1952 to 1967. Greeley grew up in Chicago, receiving his education at Catholic schools and St Mary of the Lake Seminary before doing his PhD work at the University of Chicago, even as he served a local parish from 1954 to 1964 . Greeley continued to teach off and on at the university for decades, despite an infamous tenure denial in 1973 that he attributed in part to anti-Catholicism.

Despite the many similarities between Marty and Greeley, there were also significant differences between them that shaped their invocations of the post-secular. When Marty first floated that term, in 1958, he declared it empirically inadequate. By contrast, Greeley embraced a post-secular description of American public culture in 1966. Whereas Marty discerned a new form of what Robert Bellah would soon call 'civil religion' in the postwar United States, Greeley argued that secularizing projects had run their course and Americans stood ready to re-embrace the transcendent, albeit within the matrix of a complex, industrialized society. It was Greeley's work, then, that really launched the post-secular concept. Although Greeley himself switched over to 'unsecular' by 1972, his writings gave the term post-secular currency in American scholarly debates as the 1960s gave way to the 1970 s. ${ }^{2}$ 
Nonetheless, Marty's earlier usage provides important clues about the context in which the post-secular discourse emerged: namely, debates over the meaning of the post-war revival. His 1958 Christian Century article, titled 'The Triumph of Religion-In-General', contended that 'religionin-general' had replaced Protestantism as the nation's cultural lodestone since World War II, marking a fundamental break with its religious past. Americans, he explained, remained deeply devout - perhaps more so than ever. But the character of their devotion had changed decisively. 'Multi-faceted Protestantism', wrote Marty, 'once had a virtual monopoly in forming the religious aspect of American culture'. Now, 'religion-ingeneral' reigned: 'a temporalized national religion of which Protestantism, regarded in certain lights, is seen as a part'. The particularity of that transition, coupled with certain historical continuities, led Marty to label the post-war United States 'post-Protestant', while specifying that it was clearly 'not post-Catholic, post-Jewish, [or] post-secular'. America, he concluded, 'has created a God in its own image - a highly marketable, packaged God, first harbinger of life in post-Protestant times'. After again broaching and rejecting the post-secular description in his 1959 book The Shape of American Religion, Marty abandoned it altogether. ${ }^{3}$

The post-secular, summarily dismissed at its birth, appears to have lain almost entirely dormant until Greeley picked it up and gave it new life in his August 1966 presidential address to the American Catholic Sociological Society. The published version, 'After Secularity: The Neo-Gemeinschaft Society: A Post-Christian Postscript', declared that the Church and the modern world were moving from a 'post-Christian age' into a 'post-secular age'. A number of recent developments informed Greeley's analysis. As a liberal Catholic and a parish priest, as well as a sociologist, he was centrally concerned to make Catholicism relevant to the rising generation. Greeley welcomed many of the Vatican II reforms but worried that Catholic spirituality had also lost some of its richness as the Church had come to grips with 'the modern world' and thus become 'secularized'. Yet Greeley saw a post-secular sensibility emerging among the Catholic youth of the mid 1960s, with their deep hunger for mystical, personalized forms of religious experience. $^{4}$

To capture this longing and the historical transition it portended, Greeley reached back to a conceptual distinction drawn by the late-nineteenthcentury German sociologist Ferdinand Tönnies. Observing the processes of industrialization and urbanization first-hand, Tönnies distinguished the Gemeinschaft mode, symbolized by the rural village and structured by close, affective personal bonds and a perception of sameness, from the Gesellschaft of the modern world, with its impersonal, contractual relations. Greeley, from the vantage point of the mid 1960s, now discerned the 
emergence of what he called a 'neo-gemeinschaft society'. The 'historians of the future', he wrote, would chronicle a move beyond modernization and secularization, through which Westerners had gained 'freedom and abundance', to a new phase, combining 'the freedom and affluence of a technological society with the warmth and fellowship of a tribal society'. In short, Greeley explained, a 'post-secularist' or 'post-post-Christian' society had begun to emerge. ${ }^{5}$

For Greeley, then, the post-secular concept captured the emergence of a new religious sensibility - what he termed the 'personalist revolution' - that expressed a 'hunger for new gemeinschaft in the post-secular world' and portended the emergence of a society combining the best of the modern world with key features of its premodern predecessor. Indeed, Greeley saw a broader 'revolt against the detribalized society', which strove to replace deep connections based on 'blood, land, and soil' with new bonds drawn from 'the human community' itself. Ascribing to humanity a 'desperate longing for community', Greeley expressed cautious hope that 'the postsecular community' could move beyond 'the oppression and tyranny of the old gemeinschaft society' to 'a more subtle and more sophisticated' means of forging meaningful and lasting human bonds. In doing so, he became the first American theorist to argue systematically that modern society was becoming - and should become - post-secular, in this case by combining the inner resources of the faith traditions with the external trappings of the industrialized world. ${ }^{6}$

Greeley's analysis of the nascent post-secular turn shared important features with the work of the post-war Jewish thinker Will Herberg. A former Marxist, Herberg spent the 1940s and most of the 1950s in the orbit of the Protestant theologian and ethicist Reinhold Niebuhr before ending up as the religion editor of William F. Buckley, Jr's conservative National Review. Through those years, he worked to bring themes from Niebuhr's writings into American Jewish thought, while adding the existentialist tenor of figures such as Martin Buber and Niebuhr's close colleague Paul Tillich. Like Niebuhr, but in a more pugnacious manner, Herberg rejected the longstanding tendency of Jews and theologically liberal Protestants to ally themselves with social scientists and other secular thinkers.

Herberg's writings, especially his iconic book Protestant-Catholic-Jew (1955), were key points of reference for Greeley, Marty and others of their generation as they grappled with the American religious scene in the late 1950s and early 1960s. As their scholarly identities took shape, each of the two took up Herberg's key themes: civil religion, pluralism, and the dynamics of suburban religious life. And each, like Herberg, saw something more than shallow conformity and consumerism at work in the post-war revival. Although historians typically remember Herberg's excoriation of spiritual 
celebrities such as Billy Graham and Norman Vincent Peale, he also expressed considerable hope about the spiritual longings that underpinned the revival. 'Within the general framework of a secularized religion embracing the great mass of the American people', he wrote Protestant-CatholicJew, 'there are signs of deeper and more authentic stirrings of faith'. Marty and Greeley agreed with Herberg that human beings were fundamentally religious by nature, and that the 1950s revival was both inauthentic and authentic at once. They also shared his interest in the suburbs, where Herberg believed that secularism was merely the most visible thread in a more complex religious tapestry. Despite their differences, Marty's postProtestant analysis and Greeley's post-secular vision each held out the possibility that Americans would turn their attention from the Grahams and Peales of their day toward authentic forms of faith. ${ }^{7}$

Herberg seems not to have employed the post-secular concept in expressing this hope, or in analysing religion's role in the contemporary world more broadly. However, he repeatedly applied the parallel term 'post-modern' to an emerging religious sensibility that portended a move beyond secularism's dark reign. Indeed, Herberg is the earliest American thinker I have found using the post-modern category in this manner, which dovetailed closely with the meanings Greeley and his successors attributed to the post-secular. (Others, both in Herberg's circles and beyond, used 'post-modern' between the late 1940s and the early 1960s, but only Herberg imbued it with this particular anti-secular meaning.) Beginning with a 1950 article in Reinhold Niebuhr's journal Christianity and Crisis, and continuing through his 1951 theological tract Judaism and Modern Man, a 1952 Judaism article aimed at turning Jews away from secularism, and other writings, Herberg repeatedly applied the post-modern label to a dawning historical era after secularism. 'If secularism - believing and behaving as though man were sufficient unto himself - is the mark of the modern mind', he declared, 'I think we can say that there is already beginning to emerge a mind that is post-modern'. He described this emancipated, post-modern mind as 'free from the smug self-sufficiency of secularist humanism, keenly aware of the limitations and ambiguities of naturalistic science, and therefore at last open to the power of the word of God'. In the popular religious revival, as elsewhere, Herberg detected 'growing signs of a reaction against the pervasive secularism of the past century'. ${ }^{8}$

Of course, Herberg was best known for his 1955 classic ProtestantCatholic-Jew, which has profoundly influenced accounts of American religion ever since. That book reframed Herberg's hope for a post-modern turn in sociological terms, describing such a shift as well underway in the post-war United States. Whereas Judaism and Modern Man excoriated secularism for its utter failure as an interpretation of the human condition, 
Protestant-Catholic-Jew stated flatly, as a matter of empirical fact, that avowed secularists were rapidly becoming extinct. "The "village atheist" is a vanishing figure', Herberg declared. 'These still exist, of course, but their ranks are dwindling and they are becoming more and more inconspicuous', to the point where they failed to influence American public culture. In Herberg's rendering, '[s]elf-identification in religious terms' was 'almost universal' in 1950s America. Indeed, he continued, this sensibility was especially pervasive "among the younger, "modern-minded" inhabitants of Suburbia', though it was 'rapidly spreading to all sections of the American people'. Although many saw Herberg's book as a scathing dismissal of the 1950s revival, those who read the book's closing theological chapter carefully could see that his narrative laid the sociological groundwork for religious change: an authentic revival of 'Jewish-Christian' faith. ${ }^{9}$

Herberg's hope for a move beyond secularism was hardly unique in the 1950s, but his sociological approach and adoption of the postmodern term found many reflections in the writings of Marty and Greeley. Marty's dissertation, later published as The Infidel, can be seen as an extended exploration of Herberg's 'vanishing atheist' theme. Meanwhile, his analysis of 'The God of Religion-In-General' resembled Herberg's assertion that the postwar revival currently reflected a divinization of the 'American Way', not a properly theistic outlook. A graduate adviser introduced Marty to Herberg near the end of his PhD work, and Marty later credited that encounter with turning him away from the usual practice of 'American religious history as a largely white Protestant preserve' toward 'the pluralist understanding of the Americans' spiritual journey'. ${ }^{10}$

Greeley's first study, The Church and the Suburbs, likewise reflected the influence of Protestant-Catholic-Jew, as well as his own pastoral practice. After invoking 'the American Way of Life' in the first line of his introduction, Greeley quoted at length from Herberg in a chapter on 'The Suburban Revival'. Like his elder, Greeley saw in the suburbs an entirely new mode of social existence that presented both unprecedented challenges and new opportunities - ideally, a kind of post-urban thinking with distinctive spiritual qualities. A few years later, commenting on a slightly modified version of Herberg's analysis, Greeley observed that 'nobody has yet proved Herberg wrong' and contended that the sociological research undertaken since 1955 had 'substantiated most of the things that he said'. Meanwhile, Greeley's 1966 analysis of a post-secular, 'neo-gemeinschaft' society bore some resemblance to the generational dynamic Herberg had posited in Protestant-Catholic-Jew, wherein third-generation immigrants returned to their grandparents' religious traditions but sloughed off their ethnic dimensions. As Greeley developed his account of a post-secular impulse, he, like Marty and Herberg, contended that the crudeness of much 
post-war religiosity masked spiritual impulses far deeper and more authentic than those captured by the positive-thinking gurus. Herberg's underlying message, that American religious life could be redeemed, appealed to these young, suburban minister-scholars, who hoped to make the proverbial desert - America's 'crabgrass frontier' - bloom like a rose. ${ }^{11}$

\section{Departures and convergences: Harvey Cox, Eugene Borowitz, Peter Berger and Richard John Neuhaus}

Greeley's post-secular analysis appeared just as two other young figures, the Harvard theologian-ethicist Harvey Cox and the émigré sociologist Peter Berger, set in motion a wide-ranging debate about secularism and secularization that still reverberates today. Cox's The Secular City (1965) and Berger's The Sacred Canopy (1967) reveal less of Herberg's influence than did Marty and Greeley's works, although Berger had earlier identified both Marty and Herberg as theorists of America's 'vague religiosity' and would later assert that Herberg had anticipated Robert N. Bellah's 'civil religion' concept. Nor, to my knowledge, did Cox and Berger - each born in 1929, just a year after Marty and Greeley - employ the 'post-secular' construction. Indeed, both discerned a process of secularization in the United States, though they disagreed fundamentally about that dynamic's meanings, mechanisms and implications for religion. Still, the widely read works of Cox and Berger served as common points of reference for Greeley and other theorists who saw a post-secular turn on the horizon. ${ }^{12}$

These iconic books, like Greeley's address of 1966, also captured a growing perception that American public culture was undergoing dramatic changes in the 1960s. By 1970, the historian Sydney Ahlstrom discerned 'a fundamental shift in American moral and religious attitudes'. The proliferation of 'phrases such as post-Puritan, post-Protestant, post-Christian, postmodern, and even post-historical', Ahlstrom explained, reflected the disintegration of 'the old grounds of national confidence, patriotic idealism, moral traditionalism, and even of historical Judaeo-Christian theism'. ${ }^{13}$

In The Secular City, Cox caused a stir by framing secularization as liberation, not a direct assault on religion. Like so many American Baptists before him, he called for strict separation of church and state. In a 'post-Protestant' era, he wrote, Christians could finally 'stand free enough of their culture to be against it or for it selectively, as the guidance of the Gospel suggests'. Cox identified the true danger to religion as the backlash against secularization, not that process itself. He cautioned against 'the sly temptation of a new sacral society', in the form of Marty's 'American Shinto' or Herberg's tripartite 'American religion'. In truth, Cox argued, Americans did not 
share a single religious heritage of any kind. Rather, a 'Protestant sacral culture' had been imposed on all of them as they arrived. Indeed, he argued, the 'enforced Protestant cultural religion' had harmed Protestants too, such that secularization represented liberation for all religious communities. 'It would be too bad', he wrote, 'if Catholics and Jews, having rightly pushed for the de-Protestantizing of American society and having in effect won, should now join Protestants in reconstituting a kind of tripartite American religion with Americanized versions of Moses, Luther, and Saint Thomas sharing the haloes in its hagiography'. Cox thus set himself firmly against the likes of Marty, Greeley and Herberg, who agreed, despite their many interpretive and terminological differences, that secularization destroyed genuine faith. ${ }^{14}$

That was Berger's view as well. Indeed, his account of the depredations of secularization in A Sacred Canopy was so bleak that he felt compelled to issue a mea culpa two years later for what sometimes 'read like a treatise in atheism'. Writing in 1969, Berger now emphasized 'the rediscovery of the supernatural' in his time. ${ }^{15}$ Yet neither Greeley nor Berger relied on the term 'post-secular' as the 1960s gave way to the 1970s. Rather, it made its way forward through the writings of the Reform Jewish theologian Eugene B. Borowitz, who repeatedly insisted that Jews were already post-secular, whereas Christians were still grappling with secularity.

In 1970, for example, Borowitz saw evidence that Christians were just coming to grips with modernity in a host of contemporary religious tendencies, including both 'Catholic calls to democratize the church and increase the role of the laity' and 'Protestant pleas to live out religion in the streets and through politics'. Although Borowitz agreed with Cox that 'urbanization and higher education are the keys to participating in the new secularity', he insisted that Jewish thinkers had engaged with such phenomena long ago and were now becoming 'fundamentally postsecular'. Jews, he explained, 'came through the alliance with secularity some time ago'. Now, 'a significant minority' recognized that 'beyond secularity lies the need for grounding in the transcendent. Being modern has made tradition a living option. ${ }^{16}$

Borowitz's later writings carried the post-secular concept into the very different debates of the 1980s and 1990s. To be sure, Borowitz understood the appeal of secularity, especially from a Jewish perspective. 'Jews could be citizens', he noted, only 'when the state became secular'. As a result, Borowitz contended, secularism had become for liberal Jews a 'surrogate for traditional religion, indeed so great an improvement on it - so we believed - that we invested it with messianic power'. But in the present moment, he argued, secularism 'no longer holds much promise' to Jewish leaders, who recognized that it had 'eroded the stability and significance of 
our old values'. Borowitz remained a self-proclaimed 'religious liberal' in emphasizing 'the continuing virtues of secularism', but he sought 'to direct our attention to the general loss of a ground for our values' - a project, he explained, that 'firmly situates my liberalism on a religious foundation'. Absent 'a Judeo-Christian base', Borowitz declared, 'one cannot assume that the classical ethical concerns of our society and our social liberals will have any staying power'. As he summarized in 'Beyond the Secular City' (1985), '[o]ur problem is not how to defeat secularism, but how to tame it'. Like Cox, Borowitz believed that secularism could be redeemed. ${ }^{17}$

Ultimately, however, the true inheritor of Greeley's (and Herberg's) mantle was not Borowitz but Richard John Neuhaus, a Lutheran pastor who became a Catholic priest in 1990. Like Herberg, Neuhaus was a former leftist who moved steadily rightward over the course of his long career. By the time he published The Naked Public Square in 1984, he was one of the nation's best-known critics of secularism and a key architect of today's alliance of evangelicals, Catholics, and other theological conservatives on the religious right. He had also begun to argue that a 'post-secular' era was nigh.

The Naked Public Square may seem like a paean to civil religion, but an early article from 1970 found Neuhaus arguing that Herberg, Marty and Berger had revealed 'the dangers of being taken captive by society's demands for a utilitarian religion that sanctifies business as usual'. Although the laity had ignored the lesson, Neuhaus held out hope for a concerted push 'away from the cult of relevance' in the future and the opening of 'a new period of pastoral and theological seriousness in American religion'. In the mid 1970s, Neuhaus began to display a corresponding fascination with all things 'post-'. The opening pages of his 1975 book Time Toward Home cited a plethora of such formulations as evidence of the 'apocalyptic' sense 'that we live in a time that is post-everything': 'That there is a future we are not certain; that the past is finished there is no doubt.' Still, 'post-Christian' would have fit Neuhaus's portrait of American society in 1975 better than 'post-secular'. He discerned a thoroughgoing 'crisis in public morality', wherein many socially engaged Christians had 'lost their confidence in the explicit traditions that gave religious pertinence and plausibility to their witness'. These figures, he explained, 'became so enamoured with the secular order, forgetting its dependence upon moral assumptions and their sources, that they cut themselves off from the tree's roots in order to fondle, celebrate and affirm the grace of its leaves and branches'. Neuhaus linked that 'loss of confidence' in society's Christian foundations to the publication of Cox's The Secular City, though he hastened to specify that Cox had 'represented and legitimated that loss' rather than directly caused it. ${ }^{18}$

By the early 1980s, however, Neuhaus was confidently announcing the arrival of a 'post-secular America'. He declared authoritatively: 
'We are witnessing the collapse of the 200-year hegemony of the secular Enlightenment over public discourse.' Neuhaus argued, in a populist vein, that ordinary citizens had never followed American political and religious leaders in seeking to thoroughly privatize religion. The 'worldview' of 'the great majority of Americans', he wrote, is 'tied to, and derived from, the Judeo-Christian tradition'. And that sensibility was beginning to reassert itself publicly in what Neuhaus now called a post-secular era. ${ }^{19}$

Although Neuhaus still distanced himself from the religious right in the early 1980s, he celebrated its impact on discussions of public morality. That movement, he explained, had 'triggered' a broad 'shift in American culture and politics' that was not inherently 'conservative and repressive' and could be 'turned to constructive and progressive purposes'. In Reagan's America, he argued, 'first principle questions are being asked for the first time in a long time'. (Neuhaus would go on to found the journal First Things in 1990.) Neuhaus sought 'a mediating language' that would reflect 'the Judeo-Christian tradition in which our discourse is historically rooted' but not 'leap from the Bible text to legislation or court decisions'. Even as Neuhaus decried what he soon dubbed 'the naked public square', he wrote that 'we seem to be moving into a post-secular period of American society', in which Americans were recapturing the religious and moral foundations of their social commitments. ${ }^{20}$ Here, as elsewhere, Neuhaus argued that 'the post-secular character of American society tells us something about the likely prospects of world-historical change'. ${ }^{21}$

\section{Communitarian legacies: Wilfred McClay}

Today, post-secular discourse can be heard on all sides. Even left critics increasingly decry secularism as an assault on Islam, on women, on humanity itself. The famed critical theorist Jürgen Habermas has famously abandoned his secular stance and now stresses religion's contributions to public discourse. And Peter Berger, the doughty champion of secularization theory, reversed his stance in the 1990s and began to speak of 'desecularization'. Some of today's post-secular critics argue that secularization took place but is now being reversed; others say that it never occurred at all, or that secularization is actually impossible, because all human beings harbour religious beliefs and sentiments. And one theorist, Michael Novak, has argued - in Neuhaus's own First Things - that the post-secular era itself has already come and gone. ${ }^{22}$

But communitarians and neoconservatives in the vein of Herberg, Greeley and Neuhaus remain central to the contemporary discourse of post-secularity. Although Neuhaus himself seems to have stopped using the 
term regularly by the late 1980s, he noted with satisfaction in 2006 that the 'post-secular' now figured prominently in the national conversation. He cited in particular a recent review by the historian Wilfred M. McClay of Murray Friedman's The Neo-Conservative Revolution. McClay had just become a purveyor of post-secular discourse himself, but the issues at stake in his review would have been familiar to anyone reading Neuhaus in the 1980s - or Herberg in the 1950s. Indeed, McClay underscored the steep price that Jewish neoconservatives such as Herberg and Irving Kristol had paid for joining Christian conservatives to advance 'a postsecular, post-separationist ethos' that struck their secular and liberal counterparts as 'nothing short of madness'. In McClay, once again, we see the close link between anti-secularism and criticism of strict churchstate separation that had propelled earlier discussions of secularization and the post-secular. ${ }^{23}$

From what I can discern, McClay first used 'post-secular' in 2004. Having recently co-edited a book called Religion Returns to the Public Square, ${ }^{24}$ he was part of a round table on George Marsden's biography of Jonathan Edwards. Marsden was well known for insisting that Christian scholars deserved a 'place at the table' in the modern universities, because the first principles adopted by even the most secular scholars were matters of faith and the resulting forms of knowledge were equally plausible and rational. Among Marsden's critics, McClay listed 'post-secular thinkers, Christian and otherwise', as well as theological conservatives who deemed Marsden's approach inadequate. McClay did not explicitly locate himself within the latter group, but his subsequent analysis pointed in that direction. Christians, he argued, possessed cognitive resources and insights that actually made them more capable of understanding historical phenomena than their secular counterparts..$^{25}$

Since then, McClay has continued to employ the post-secular idiom, usually to register his sense that secularism no longer dominates Western public cultures. ${ }^{26}$ Most typically, McClay has used the term to announce the dawn of an age that finally saw through the pretensions of secularism. As he wrote in 2010, 'we now face a new era in Western history - an era in which the long-predicted obsolescence of religion is itself being rendered obsolete, and a fresh, post-secular understanding of the future is emerging into view'. This claim appeared alongside blurbs by the communitarian writers Michael Novak and George Weigel on the back of a book titled The God That Did Not Fail. The author, the conservative Catholic writer Robert Royal, had earlier sought to rehabilitate Christopher Columbus and now took on revisionist accounts of the founding generation, insisting that secularism was a recent innovation and 'all the main American Founders believed in a strong connection between religious belief and the health of 
the republican form of government'. Like Marsden and McClay, Royal contended that a state 'neutral among religions and irreligion' actually 'imposed a uniform secularism on the nation' and thus stamped out true pluralism. ${ }^{27}$

This remains the primary meaning of the post-secular for McClay, as for many others. In this usage, the term announces the onset of a new era of friendliness toward religion and scepticism toward secularism. In a 2008 essay on 'American Thought and Culture in the 21st Century', for example, McClay asked rhetorically: 'Who would have imagined, even two decades ago, the kinds of debates we would see roiling the post-9/11 world, at a moment when the immense motivational power of religion has roared back into view, as potent as a force of nature?' Indeed, he asserted that 'the secular worldview, whose triumph once seemed so inevitable, now seems stalled, and even to be losing ground, or being superseded'. Who, any more, could believe that 'the dream of a fully secularised public life, a condition that Richard John Neuhaus memorably labelled as "the naked public square"', was either plausible or desirable? Unusually, McClay here distinguished the post-secularity of the United States from the more secular climate of Europe and explained the religion's resurgence was not merely a matter of its own persistence but also the failure of secularism to provide 'an adequate framework for the great mass of Americans to lead meaningful, morally coherent lives'. ${ }^{28}$

Indeed, McClay presented his analysis in populist terms. He saw a dialectical process at work in American history, wherein the deep piety of the population acted as a brake on the claims of 'militant secularists', who had recently 'overreached' and produced the inevitable backlash. 'Atheists', he declared, had always found a broad American audience for their resistance to 'the coercions of any religious establishment, formal or informal'. Yet, 'when they take matters further, and insist that because religion "poisons everything" its public expression should be discouraged and ridiculed, if not actively suppressed, then their position becomes eccentric and marginal, and pushes the mainstream back toward a more religion-friendly centre'. ${ }^{29}$

McClay linked the homespun wisdom of the American people to a more universal, global perception of modernity's shortcomings: a growing realization that religion was crucial for asserting 'human dignity and moral order in a postmodern world dominated by voracious state bureaucracies and sprawling transnational business corporations'. In short, McClay summarized, religion offered 'a necessary corrective to the dehumanising effects of technocratic modernity, an avenue of escape from the iron cage'. McClay's analysis thus pointed in the same direction as Greeley's earlier concept of a 'neo-gemeinschaft society'. Rebutting the claims of 'New Atheists' such as 
Richard Dawkins and Sam Harris, he contended that 'in America it is secularism, rather than religion, whose power is ebbing away'. ${ }^{30}$

Like so many other communitarian and neoconservative contributors to the post-secular discourse, McClay referred back to the debates of the 1950s and 1960s over the post-war revival and civil religion, and beyond that to the writings of Rousseau and Durkheim. The 9/11 attacks, he wrote, 'reminded us of something that the best social scientists already knew - that the impulse to create and live inside of a civil religion is an irrepressible human impulse, and that this is just as true in the age of the nation state'. This was true, as both Durkheim and Robert Bellah had recognized, because 'the state itself is something more than just a secular institution': 'Because it must sometimes call upon its citizens for acts of sacrifice and self-overcoming, and not only in acts of war, it must be able to draw on spiritual resources, deep attachments, reverent memories of the past, and visions of the direction of history to do its appropriate work.' McClay thus aligned himself with Bellah's argument that American civil religion possessed substantive, authentic religious content. He contrasted this respectful, and in his view empirically grounded, approach to Herberg's dismissal of civil religion as simply nationalism and consumerism run amok. ${ }^{31}$

Yet McClay also adopted the sociologist Robert Wuthnow's claim that Americans actually possessed two civil religious traditions, one appealing to religious conservatives and the other to religious liberals. Emerging in the early twentieth century, Wuthnow explained, this split was largely smoothed over in the 1940s and 1950s but reasserted itself with a vengeance thereafter, leaving Americans deeply divided on whether their nation possessed a providential mission to spread 'traditional American values and institutions' or whether the Bible and the nation's founding documents alike called for progressive interventions in the name of equality. Amid this dispute, according to McClay, the post-secular era had dawned. Although religious belief had always been 'astonishingly pervasive' in the United States, the 'desecularisation' process had begun in earnest with the political maturation of the religious right. 'Ever since the election of Jimmy Carter as President in 1976', McClay explained, 'the taboos on public expression of religious sentiments by American political leaders seem to have been steadily eroding. 32

Still, McClay noted that the period before 9/11 had brought sharp, Herberg-style critiques of civil religion. Even Bellah had distanced himself from the concept, he noted. Meanwhile, believers of all stripes had joined Stanley Hauerwas in adopting a 'separationist' stance based on 'a growing sense that the American civil religion has become a pernicious idol, antithetical to the practice of their faith'. Yet 9/11 'changed all of that 
decisively', wrote McClay. He marvelled at 'how quickly the ailing civil religion seemed to spring back to new life', giving post-secular impulses a new 'urgency' and 'intensity': 'Coming at a moment when Americans had been gradually rethinking many settled precedents regarding religion and public life, the $9 / 11$ attacks seemed to give a sharper edge to the questions being asked' and forced a 'choice between radically different perspectives on the proper place of religion in modern Western society'. In the wake of that catastrophe, McClay declared, it was less plausible than ever to describe the United States as a secular nation. Amid the polemics of fundamentalists and atheists, the American public in the wake of 9/11 did what it had always done, avoiding extreme positions and seeking 'something much simpler and more primal': 'Millions of Americans went to church, searching there for reassurance, for comfort, for solace, for strength, and for some semblance of redemptive meaning in the act of sharing their grief and confusion in the presence of the transcendent.' In short, '9/11 produced a great revitalisation, for a time, of the American civil religion'. ${ }^{33}$

Still McClay contended that the split between competing models of civil religion had quickly reasserted itself and hesitated to offer any firm predictions for the future. In the end, McClay concluded, one could never predict the future of religion with any certainty. 'The spirit bloweth where it listeth, and the paths taken by religious faith are not always obvious ones', he wrote. 'The only conclusions in which we can be entirely confident of our extrapolations are conclusions that warn us of the dangers of extrapolation', such as that undertaken by 'prophets of inevitable secularism'. Indeed, only one thing remained certain: '[T]hat, whatever some individual Americans may think, religion remains a powerful force that is not leaving the stage anytime soon.' If secularization were ever to actually occur, it would be in the distant future. For McClay, the central dynamics in postsecular America were a potent desecularizing impulse and an even older division between the religious left and right. ${ }^{34}$

McClay's formulation of the post-secular matters because of how influential his framing of the secular itself has been. His widely cited 2000 essay 'Two Concepts of Secularism' captured and codified an understanding of secularism that reverberated through innumerable American discussions in the twentieth century and tells us much about the tenor of the postsecular discourse. Like hundreds of American critics before him, McClay distinguished two forms of secularism. (Most of the earlier interpreters had identified these models as American and French, respectively, but McClay saved that charge of foreignness for a later essay.) One was 'a minimal, even "negative", understanding of secularism' that was 'almost identical to the language of the First Amendment' and was decidedly friendly to 
religion. This approach, 'equally respectful of religionists and nonreligionists alike', enforced 'the freedom of the uncoerced individual conscience' but showed 'a capacious understanding of the religious needs of humanity' and the inevitably social character of religion, which made 'the right of free association ... just as important as the right of individual expression'.

On the other side, McClay continues, 'the more militant secularists, whom we can call the establishmentarian or "positive" secularists', viewed secularism as a 'crusading ideal' that required the establishment of 'unbelief' itself, by confining 'religion to a strictly private sphere, where it can do little public harm - and little public good'. Convinced of their own neutrality, McClay asserted, the advocates of positive secularism considered themselves neutral but were actively 'creating and enforcing the naked public square'. As 'an ultimate and alternative comprehensive faith' rooted in the dogmatic 'ideal of self-mastery', McClay concluded, positive secularism directly threatened religion in a way that negative secularism, with its simple insistence on non-establishment, could never do. ${ }^{35}$

\section{Post-secularism and the church-state question}

McClay is hardly alone in equating the onset of post-secularity with the ouster of a 'positive secularism' - one that he believes contradicted the experience and institutions of the United States - and the restoration of a healthy, quintessentially American 'negative secularism' that allows all religions to flourish and ensures their equal status in the public eye. Postsecularism, in this vein, does not mean the total disappearance of secular worldviews. Rather, it means the reconfiguration of the public square as a space featuring robust, foundational arguments from the proponents of all worldviews, religious or secular.

Religion scholars have long noted that theories of religion and society, including theories of secularization, tend to discipline religious faith by distinguishing good religion from bad. As the post-secular discourse shows, such theories also delineate good secularism from bad and good pluralism from bad. It is incumbent upon scholars, then, to understand how advocates and other commentators have used terms such as 'post-secular'. In its communitarian and neoconservative guises - the guises it wore almost exclusively during its early years - the post-secular discourse goes beyond simple advocacy of religious faith. It implies a particular understanding of church-state relations, and of religion's centrality to public affairs, that many religious believers themselves - including Harvey Cox and his allies rejected. Specifically, this version of post-secularism dovetails with the 'non-preferentialist' or 'accommodationist' argument that the state must 
be neutral between religions but cannot be neutral with regard to religion and irreligion. That understanding enshrines a particular definition of not only the term 'secularism' but also categories such as 'pluralism' and 'religious freedom', as well as the broader concept of religious authenticity itself. ${ }^{36}$

Indeed, such theorists often argue that secularism is sufficiently powerful and pervasive to snuff out the post-secular age in its infancy, should authentic believers fail to see and meet the existential threat it poses. In a 2020 article, McClay touted a historic rapprochement between 'believing Christians and believing Jews' who had joined hands in part to protect genuine, Judeo-Christian faith against the ultimate product of the Enlightenment: 'An ascendant secular nihilism, increasingly militant and seemingly intent upon sweeping away the moral, cultural and institutional norms that have defined our shared civilization for millennia.' This portrait of the contemporary world indicts not only unbelievers but also the prevailing forms of liberalism, both religious and political. And it underscores that delineating the good from the bad and the winners from the losers - as all debates around post-terms tend to do - can have striking implications in the real world. ${ }^{37}$

\section{Notes}

1 Beyond these commonalties, Marty also sat on the dissertation committee of Greeley's sister. Andrew M. Greeley, 'Andrew Greeley Replies to His Critics', Journal for the Scientific Study of Religion, 13:2 (1974), 229.

2 Andrew M. Greeley, Unsecular Man (New York: Shocken, 1972).

3 Martin E. Marty, 'The Triumph of Religion-in-General', Christian Century, 75:37 (1958), 1016-17 (italics omitted). In the 1959 book, based on the Christian Century articles, Marty again called the late 1950s 'post-Protestant times' - as opposed to, say, 'post-Catholic, post-Jewish, or post-secular times', The New Shape of American Religion (New York: Harper, 1959), p. 32. On the post-Protestant discourse, see Curtis Scott Drumm, 'Post-Protestant America? A Critique of Historiographical Models of Protestantism's Decline' (PhD dissertation, Southwestern Baptist Theological Seminary, 1999).

4 Andrew M. Greeley, 'After Secularity: The Neo-Gemeinschaft Society: A PostChristian Postscript', Sociological Analysis, $27: 3$ (1966), 119-20. Greeley almost certainly drew on one precedent from the intervening years. He had reviewed a 1964 volume, co-edited by Marty, that featured a chapter on 'The Pastor and Social Conflict' by the Hungarian-born Presbyterian John R. Bodo. In his chapter, Bodo twice used the term 'post-secular': Robert Lee and Martin E. Marty (eds), Religion and Social Conflict (New York: Oxford, 1964), pp. 154, 160. Greeley deemed Bodo's essay 'undistinguished' but may have picked up the 
post-secular category from it. Greeley, review of Lee and Marty (eds), Religion and Social Conflict (New York: Oxford, 1964), in Sociological Analysis, 27:1 (1966), 50-1.

5 Greeley, 'After Secularity', 125-6.

6 Ibid., 125.

7 Will Herberg, Protestant-Catholic-Jew: An Essay in American Religious Sociology (Garden City, NY: Doubleday, 1955), p. 288; K. Healan Gaston, 'The Cold War Romance of Religious Authenticity: Will Herberg, William F. Buckley, Jr, and the Rise of the New Conservatism', Journal of American History, 99:4 (2013), 1133-58.

8 Will Herberg, 'Secularism In Church and Synagogue', Christianity and Crisis, 10:8 (1950), 60-1; Herberg, Judaism and Modern Man: An Interpretation of Jewish Religion (Philadelphia, PA: Jewish Publication Society of America, 1951), p. 7 (and cf. p. 163); Herberg, 'Jewish Existence and Survival: A Theological View', Judaism, 1 (January 1952), 26. Union Theological Seminary president Henry P. Van Dusen, a colleague of Niebuhr and Tillich, casually invoked 'postModern' as an alternative to 'post-Christian' in a 1948 article, but he made no attempt to define it. 'It is sometimes loosely said today that we are living in the "post-Christian" era', Van Dusen wrote. 'That is a misstatement. But it may be said that we are moving into the "post-Modern" era. As has been often said, "it is the end of our time".' 'Revolution and Christian Response', Anglican Theological Review, 30:3 (1948), 145.

9 Herberg, Protestant-Catholic-Jew, p. 274; Gaston, 'The Cold War Romance of Religious Authenticity'.

10 Marty quoted Herberg at length in the earlier work, highlighting his claim that " "[r]eligion has become part of the ethos of American life to such a degree that overt anti-religion is all but inconceivable."' The Infidel (New York: Meridian, 1961), pp. 190-1.

11 Andrew M. Greeley, The Church and the Suburbs (New York: Sheed \& Ward, 1959), p. xi, pp. 41-9; Greeley, review of Religion and Social Conflict, 50-1. Herberg figured prominently as a contributor in a volume that Marty and Greeley later co-edited with Stuart E. Rosenberg, What Do We Believe? The Stance of Religion in America (New York: Meredith Press, 1968). Rosenberg, too, may have been influenced by Herberg as a student at the Jewish Theological Seminary and Columbia University, two institutions within Herberg's orbit. Moreover, he knew Marty's work well and shared his interest in the suburbs. On his career, see Michael Brown, 'Platform and Prophecy: The Rise and Fall of Rabbi Stuart E. Rosenberg as Foreshadowed in His Early Toronto Sermons on Leadership', Jewish History, 23:2 (2009), 195-217.

12 Harvey Cox, The Secular City: Secularization and Urbanization in Theological Perspective (New York: Macmillan, 1965); Peter L. Berger, The Sacred Canopy: Elements of a Sociological Theory of Religion (Garden City, NY: Doubleday, 1967); Berger, The Noise of Solemn Assemblies: Christian Commitment and the Religious Establishment in America (Garden City, NY: Doubleday, 1961), pp. 41-2; Berger, Religion in a Revolutionary Society (American Enterprise 
Institute for Public Policy Research, 1974). Cox invoked the term in the introduction to a 2013 reprint (Princeton, NJ: Princeton University Press) of his classic text.

13 Sydney E. Ahlstrom, 'The Radical Turn in Theology and Ethics: Why It Occurred in the 1960s', Annals of the American Academy of Political and Social Science, 387 (1970), 3.

14 Cox, The Secular City, pp. 118-19.

15 Peter L. Berger, A Rumor of Angels: Modern Society and the Rediscovery of the Supernatural (Garden City, NY: Doubleday, 1969).

16 Eugene B. Borowitz, 'Jewish Theology Faces the 1970's', The Annals of the American Academy of Political and Social Science, 387 (1970), 27, 22. Borowitz employed a chronologically narrower understanding of the post-secular than others, emphasizing secularity's broken promises to Jews since World War I. Eugene Borowitz, 'The Post-Secular Situation of Jewish Theology', Theological Studies, 31:3 (1970), 460. On Borowitz, see especially Hava Tirosh-Samuelson and Aaron W. Hughes (eds), Eugene B. Borowitz: Rethinking God and Ethics (Leiden: Brill, 2014).

17 Borowitz, Exploring Jewish Ethics: Papers on Covenant Responsibility (Detroit, MI: Wayne State University Press, 1990), pp. 96, 109, 39-40, 61.

18 Richard John Neuhaus, 'The War, the Churches, and Civil Religion', Annals of the American Academy of Political and Social Science, 387 (January 1970), 133, 138; Neuhaus, Time Toward Home: The American Experiment as Revelation (New York: Seabury Press, 1975), pp. 1, 85, 20. By the late 1960s, Berger and Neuhaus were locked in dialogue. Berger thanked Neuhaus for their lengthy discussions in the preface to A Rumor of Angels. In 1970, the pair co-wrote a book in which Berger called for gradual, ameliorative change while Neuhaus, then still a leftist, championed a revolution: Movement and Revolution (Garden City, NY: Doubleday, 1970). But the two Lutherans shared theological common ground and Neuhaus quickly moved away from his revolutionary politics. In 1975, they gathered a group of religious thinkers to craft the 'Hartford Appeal for Theological Affirmation', enumerating and repudiating various forms of 'capitulation to the alleged primacy of modern thought'. The group rejected humanistic and naturalistic understandings of religion, affirmed the rationality of religious language and the importance of religious institutions, and emphasized God's transcendence and the reality of 'hope beyond death'. 'An Appeal for Theological Affirmation', in Berger and Neuhaus (eds), Against the World for the World: The Hartford Appeal and the Future of American Religion (New York: Seabury, 1976), pp. 1-7.

19 Richard John Neuhaus, 'Educational Diversity in Post-Secular America', Religious Education, 77:3 (1982), 309-10. Neuhaus first used 'post-secular' in 'The Post-Secular Task of the Churches', in Carol Friedley Griffith (ed.), Christianity and Politics: Catholic and Protestant Perspectives (Washington, DC: Ethics and Public Policy Center, 1981), pp. 1-18.

20 Neuhaus, 'Educational Diversity in Post-Secular America', 313-14, 320.

21 Richard John Neuhaus, 'Moral Leadership in Post-Secular America', Educational Freedom, 11:7 (1982), 10. It should not surprise us by now to 
find that Neuhaus drew on Will Herberg's writings and example, as a fellow Marxist-turned-conservative. Shortly after Neuhaus published The Naked Public Square, he declared his intellectual indebtedness to Herberg in 'Will Herberg: A Passion for Authenticity', National Review (31 December 1985), 83-4 and 'Will Herberg: Pluralist', National Review (22 January 1988), 54. The latter piece called Herberg 'the avant garde of a rebirth of vibrant pluralism'. In addition to serving as 'Bill Buckley's confessor', Neuhaus argued, Herberg stood 'alone among Jewish thinkers of his time' in rejecting 'the platitudes of mere tolerance' and becoming a 'true pluralist' - that is, 'a pluralist in his understanding of the connections between religion, moral judgment, and the social order'.

22 Michael Novak, 'Remembering the Secular Age', First Things, 174 (2007), 35-40.

23 Richard John Neuhaus, 'The Public Square: A Continuing Survey of Religion, Culture, and Public Life', First Things, 167 (2006), 63-80; Wilfred M. McClay, review of Friedman, The Neo-Conservative Revolution, in Commentary (February 2006), 74.

24 Wilfred M. McClay, Religion Returns to the Public Square: Faith and Policy in America (Baltimore, MD: Johns Hopkins University Press; Washington, DC: Woodrow Wilson Center Press, 2003).

25 Wilfred M. McClay, 'Completion or Revision', Historically Speaking, 5:6 (2004), 17-18.

26 For a more ambiguous rendering of the term, see Wilfred M. McClay, 'Winter Stories', Commentary, 132:5 (2008), 75-6.

27 Robert Royal, The God That Did Not Fail (New York: Encounter Books, 2006), back cover, 270-1. The earlier book is Royal, 1492 and All That: Political Manipulations of History (Washington, DC: Ethics and Public Policy Center, 1992).

28 Wilfred M. McClay, 'Religion in Post-Secular America', in Martin Halliwell and Catherine Morley (eds), American Thought and Culture in the 21st Century (Edinburgh: Edinburgh University Press, 2008), pp. 127-8.

29 Ibid., p. 128.

30 Ibid.

31 Ibid., pp. 139, 134.

32 Ibid., pp. 139, 129.

33 Ibid., pp. 136-7, 130-1.

34 Ibid., pp. 138, 141.

35 Wilfred M. McClay, 'Two Concepts of Secularism', Wilson Quarterly, 24:3 (2000), 63-7. The French comparison appears in 'Secularism, American-Style', Sociology, 44 (2007), 160-3. McClay later dubbed these modes 'political secularism' and 'philosophical secularism' (Pew Research Center, 'Religion and Secularism: The American Experience', www.pewresearch.org/2007/12/03/ religion-and-secularism-the-american-experience/, accessed 17 August 2020) but also continued to develop the positive-negative distinction, as in 'Secularism, American-Style'. 
36 For a characteristic earlier statement of this church-state position, see Neuhaus, 'Educational Diversity in Post-Secular America', 314.

37 Wilfred M. McClay, 'What Christians See in Jews and Israel in 2020 of the Common Era', Mosaic (July 2020), https://mosaicmagazine.com/essay/historyideas/2020/07/what-christians-see-in-jews-and-israel-in-2020-of-the-commonera/ (accessed 31 August 2020). 